JAMP: Jurnal Adminitrasi dan Manajemen Pendidikan

Volume 1 Nomor 2 Juni 2018, Hal : 238-244

Tersedia Online di http://journal2.um.ac.id/index.php/jamp/

ISSN 2615-8574 (online)

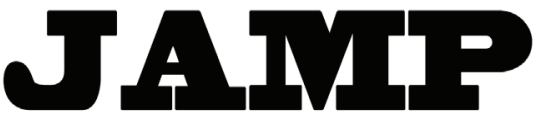

\title{
IMPLEMENTASI PROGRAM PENGUATAN PENDIDIKAN KARAKTER MELALUI KEGIATAN PEMBIASAAN DALAM PENINGKATAN MUTU SEKOLAH
}

\author{
Silvya Eka Andiarini \\ Imron Arifin \\ Ahmad Nurabadi \\ silvyaeka12@gmail.com \\ Universitas Negeri Malang, Jl. Semarang No. 5 Malang 65145
}

\begin{abstract}
The purposes of this research to describe: (1) planning, (2) implementation, (3) role of school citizen, and (4) inhibiting and supporting factors in Character Education Improvement program through habituation activities in improving school quality. This research uses qualitative approach, with case study research design at SMPN 1 Wlingi Blitar. Data collection techniques interview, observation and documentation. The analysis techniques are reduction, display and conclusion. The results of this study (1) planning starts from SKL to socialization, (2) implementation through habituation activities implemented in 2 bases, class and school, (3) the role of school citizens such as supervisors, builders and implementers of PPK activities. (4) supporting and inhibiting factors are to learners, teachers, facilities and the involvement of the school committee and parents.
\end{abstract}

Keywords: character education, habituation activities, implementation

\begin{abstract}
Abstrak: Penelitian ini bertujuan untuk mendeskripsikan: (1) perencanaan, (2) pelaksanaan, (3) peran warga sekolah, (4) faktor pendukung (5) faktor penghambat dan (6) solusi dalam program Penguatan Pendidikan Karakter melalui kegiatan pembiasaan dalam peningkatan mutu sekolah. Penelitian ini menggunakan pendekatan kualitatif, dengan rancangan penelitian studi kasus di SMPN 1 Wlingi Blitar. Teknik pengumpulan datanya wawancara, observasi dan dokumentasi. Teknik analisisnya reduksi, display dan penarikan kesimpulan. Hasil penelitian ini (1) perencanaan dimulai dari SKL sampai sosialiasasi, (2) pelaksanaan diterapkan dalam dua basis: kelas dan sekolah, (3) peran warga sekolah sebagai pengawas, pembina dan pelaksana. (4) faktor pendukung dan penghambat ialah pada peserta didik, guru, fasilitas serta keterlibatan pihak komite sekolah dan orangtua.
\end{abstract}

Kata kunci: implementasi, kegiatan pembiasaan, pendidikan karakter

Runtuhnya nilai moral di kehidupan masyarakat saat ini juga berdampak buruk pada nilai dan sikap anak remaja pada saat ini. Hal ini disebabkan dari beberapa faktor yang mempengaruhi juga, salah satu faktor yang paling kuat adalah penggunaan gadget pada anak usia sekolah menengah pertama. Dimana mereka mudah sekali terpengaruh dalam perkembangan tren dan sosialisasi yang ada di media sosial. Sehingga pihak orang tua harus ekstra dalam mendidik anak di rumah. Turunnya etika dan moral ini juga membuat sekolah harus bekerja sangat keras dalam mendidik dan menyampaikan ilmu pengetahuan kepada para peserta didiknya. Salah satu cara memperbaiki kemerosotan moral ini adalah dengan menggunakan pendidikan karakter yang tak hanya di rumah, namun juga secara terstruktur di sekolah.

Salah satu upaya pemerintah tentang pendidikan karakter adalah Penguatan Pendidikan Karakter (PPK) yang terintegrasi dalam Gerakan Nasional Revolusi Mental, yaitu perubahan cara berpikir, bersikap 
dan bertindak menjadi lebih baik (Azwar, 2017). PPK merupakan lanjutan dari program sebelumnya yang memberikan solusi terhadap turunnya moral anak bangsa, karena menurut Kemendikbud (2017) salah satu urgensi PPK adalah "Keterampilan abad 21 yang dibutuhkan siswa guna mewujudkan keunggulan bersaing Generasi Emas 2045: Kualitas Karakter, Literasi Dasar, Kompetensi 4 C (Critical Thinking an Problem Solving, Creativity, Communication Skills, dan Ability to Work Collaboratively)". Melalui program tersebut, kemampuan anak baik dalam kepribadian maupun life skills-nya akan berkembang baik seiring dengan berkembangnya teknologi yang ada dan tentunya dapat mengurangi dampak buruknya. Beberapa sekolah telah menerapkan dan mengimplementasikan program diatas sesuai dengan kebutuhan sekolah. Sesuai dengan kebutuhan sekolah ini juga diartikan sebagai cara yang disesuaikan dengan kebutuhan sekolah seperti kegiatan pembiasaan dan lain sebagainya.

Pada dasarnya pendidikan formal di sekolah akan sangat membantu jika pihak sekolah menekankan pada pendidikan yang membentuk karakter anak. Seiring dengan lunturnya nilai moral di masyarakat saat ini membuat sekolah harus dapat meningkatkan mutu pendidikannya dan memperbanyak program pendidikan karakter. Menurut Hamid (2017:3) "Sekolah (pendidikan) merupakan salah satu tempat yang strategis dalam pembentukan karakter selain di keluarga dan masyarakat". Hal itulah yang mendasari perlu adanya program pendidikan karakter di sebuah sekolah, baik di dalam kelas maupun di luar kelas. Maka dari itu perlu penanaman pendidikan karakter untuk tiap sekolah dengan berbagai kegiatan yang bisa menunjang penanaman karakter yang baik ini. Salah satu kegiatan yang bisa dilakukan untuk menguatkan dan menanamkan nilai-nilai karakter adalah dengan kegiatan pembiasaan yang dilakukan di sekolah. Karena memang hal yang rutin dilakukan setiap hari akan tertanam dengan baik dalam diri peserta didik maupun warga sekolah yang lain. Maka dari itu kegiatan pembiasaan ini menjadi kegiatan yang sangat penting bagi terlaksananya pendidikan karakter yang ada di sekolah. Seperti yang dijabarkan oleh Wibowo (2013:21-22) bahwa "Nilai-nilai pendidikan karakter juga harus ditumbuhkan lewat kebiasaan kehidupan keseharian di sekolah (habituasi), melalui budaya sekolah karena budaya sekolah (school culture) merupakan kunci dari keberhasilan pendidikan karakter itu sendiri". Salah satu sekolah yang menerapkan PPK melalui kegiatan pembiasaan dalam rangka peningkatan mutu adalah SMPN 1 Wlingi Blitar.

Peneliti memilih SMPN 1 Wlingi Blitar sebagai lokasi penelitian disebabkan sekolah ini telah ditunjuk sebagai sekolah percontohan atau sekolah model dengan pelaksanaan Sistem Penjaminan Mutu Internal (SPMI), kemudian sekolah ini juga salah satu sekolah yang menerapkan Manajemen Berbasis Sekolah dan mendapat himbauan untuk menjadi sekolah yang menerapkan PPK. Selain itu SMPN 1 Wlingi Blitar juga dikenal sebagai sekolah yang memiliki budaya sekolah yang baik dan memiliki nilai ujian terbaik se-kabupaten Blitar walapun sekolah ini memiliki 2 gedung pembelajaran yang berbeda lokasi. Selain itu predikat sekolah Adiwiyata tingkat Propinsi juga diraihnya pada tahun 2017 kemarin. Sehingga tak hanya terkait pendidikan karakter mengenai nila religius dan akhlak mulia saja yang dikembangkan sekolah, namun juga mengenai nilai kepedulian terhadap lingkungan hidup.

\section{METODE}

Penelitian ini menggunakan pendekatan kualitatif, dengan rancangan penelitian yang digunakan adalah studi kasus. Teknik pengumpulan data diperoleh melalui wawancara mendalam, pengamat sebagai partisipasipan dan dokumentasi. Penelitian dilaksanakan dengan mengumpulkan data terlebih dahulu dari lapangan dimana situs penelitiannya yaitu SMPN 1 Wlingi. Data penelitian yang telah didapatkan melalui beberapa teknik pengumpulan tadi kemudian dilakukan analisis dengan cara mereduksi data sesuai dengan kebutuhan dari fokus penelitian. Data yang telah direduksi kemudian disajikan dan ditarik kesimpulannya. Informan kunci dalam penelitian ini adalah kepala sekolah, sedangkan data lain yang mendukung didapatkan melalui informan tambahan yaitu beberapa guru, satpam, tukang kebun dan peserta didik. Pengecekan keabsahan data dilakukan peneliti untuk mempertanggungjawabkan kebenaran dari data yang telah didapatkan. Keabsahan data dilakukan melalui teknik kredibilitas yang diantaranya triangulasi, perpanjangan waktu pengamatan, meningkatkan ketekunan, dan kecukupan referensial. 


\section{HASIL}

\section{Perencanaan Penguatan Pendidikan Karakter melalaui kegiatan pembiasaan dalam peningkatan mutu sekolah}

Proses perencanaan kegiatan pembiasaan untuk PPK di SMPN 1 Wlingi dilaksanakan melalui SPMI, yang langkahnya sebagai berikut: (1) Setelah adanya himbauan dari Kepala Dinas melalui pertemuan dan setelah itu Kepala Sekola menyampaikan ke para guru dan staf yang kemudian ditindaklanjuti dengan pembuatan proposal program sekolah atau penyusunan Standar Kompetensi Lulusan (SKL). Dimana penyusunan ini didasarkan pada permasalahan yang dihadapi pada saat pelaksanaan yang lalu, terkadang juga melalui EDS serta supervisi yang dilakukan oleh kepala sekolah; (2) Hasil penyusunan tersebut disampaikan pada dewan pendidikan yang terdiri dari guru, komite sekolah dan perwakilan paguyuban melalui pertemuan; (3) Ketika program telah disetujui, maka program tersebut akan dimasukkan ke dalam Buku 1 Kurikulum atau lebih jelasnya pada struktur kurikulum dan mendapat tanda tangan resmi dari komite sekolah juga; (4) Otomatis ketika program tersebut sudah masuk ke dalam struktur kurikulum, maka akan masuk juga pada pengelolaan di 8 standar, terutama pada RPP guru; (5) Program ini juga akan merubah jadwal pelajaran baik 5 hari sekolah (LHS) maupun 6 hari masuk sekolah. Kemudian dari beberapa program tersebut muncul SOP kelas yang menyertakan kegiatan pembiasaan di kelas; dan (6) Setelah seluruh program siap, kemudian pihak sekolah menyampaikan program tersebut ke wali murid, terutama wali murid peserta didik baru.

\section{Pelaksanaan Penguatan Pendidikan Karakter melalaui kegiatan pembiasaan dalam peningkatan mutu sekolah}

Pelaksanaan PPK melaui kegiatan pembiasaan di SMPN 1 Wlingi diterapkan pada 2 basis. Yakni berbasis kelas dengan kegiatannya adalah 1) membaca kitab suci, 2) kegiatan literasi, 3) kegiatan Pra KBM (membaca Pancasila, menyanyi Lagu Indonesia Raya dan berdoa), 4) mengucapkan salam kepada guru di awal dan di akhir pembelajaran, dan 5) kebersihan kelas sebagai wujud program Adiwiyata . Sedangkan untuk yang berbasis budaya sekolah diterapkan dengan beberapa kebiasaan utama seperti 1) bersalaman ketika bertemu guru, 2) turun dari sepeda ketika memasuki gerbang sekolah, 3) aturan keluar masuk sekolah dan kelas, 4) pelaksanaan upacara, 5) budaya 5S, 6) program adiwiyata, 7) kegiatan keagamaan: sholat berjamaah dan kegiatan Madin, serta 8) program ASBN dan PIK-R.

\section{Peran warga sekolah pada program Penguatan Pendidikan Karakter melalui kegiatan pembiasaan dalam peningkatan mutu sekolah}

Pelaksanaan dari PPK melalui kegiatan pembiasaan melibatkan seluruh komponen sebagai berikut: (1) Kepala sekolah, bertindak sebagai pengawas yang mengawasi dan membina mulai dari guru, staf dan karyawan bahkan peserta didik. Untuk membina guru staf dan karyawan biasanya dilakukan dengan rapat dinas. Sedangkan untuk peserta didik dilakukan dengan pengarahan langsung di kelas-kelas atau di dalam amanat upacara; (2) Guru, bertidak sebagai orang yang melaksanakan PPK itu sendiri di dalam kelas. Baik yang tercantum pada RPP maupun tidak. Selain itu guru juga bertindak mengawasi dan membina peserta didik di luar kelas pada setiap pelaksanaan pembiasaan. Guru juga harusnya bisa mengingatkan rekan yang lainnya dalam pelaksanaan PPK ini; (3) Satpam, selain mengamankan dan mentertibkan peserta didik, satpam di SMPN 1 Wlingi juga bertugas sebagai pelatih upacara untuk peserta didik yang bertugas menjadi petugas upacara; (4) Tukang Kebun, beliau bertugas sebagai teknisi sekolah juga yang mengecek dan mempersiapkan segala peralatan yang diperlukan dalam kegiatan PPK melalui kegiatan pembiasaan. Beliau juga membantu dalam mendidik peserta didik mengenai lingkungan, kebersihan dan juga tanaman namun tidak secara langsung; (5) Komite Sekolah dan Paguyuban, dimana mereka sangat berperan dalam pelaksanaan terkait mungkin dana yang mereka berikan untuk melancarkan kegiatan. Selain itu mereka juga mengawasi jalannya kegiatan serta juga sebagai penanggungjawab atas keberlangsungan salah satu kegiatan yang mereka danai; dan (6) Tenaga Administrasi Sekolah, dimana semua orang harus terlibat dalam PPK sehingga untuk warga sekolah yang lain harus tetap saling mengingatkan dan memberi teladan terhadap warga sekolah yang lain. 


\section{Faktor pendukung pada program Penguatan Pendidikan Karakter melalui kegiatan pembiasaan dalam peningkatan mutu sekolah}

Pelaksanaan PPK melalui kegiatan pembiasaan di SMPN 1 Wlingi memiliki hal pendukung dan penghambat adalah sama. Namun, memang dari sudut pandang dan permasalahan yang berbeda. Seperti pada faktor pendukung: (1) Komitmen guru dalam menjalankan peran sangat mempengaruhi efektifitas dari pelaksanaan PPK melalui kegiatan pembiasaan. Yang mana guru memiliki banyak peran yakni sebagai pengawas pelakasanaan pembiasaan di pagi hari, sebagai pembina kegiatan keagamaan (tidak semua guru), mentertibkan peserta didik dalam beberapa kegiatan, serta memberi teladan pada saat di kelas maupun di luar kelas; (2) Keterlibatan peserta didik dalam pelaksanaan ini dimaksudkan adalah membantu proses pengawasan serta terlibat langsung dalam kegiatan sehingga memberikan teladan yang baik bagi peserta didik yang lain. Peserta didik ini adalah anggota OSIS, ASBN, PIK-R dan POKJA; (3) Optimalisasi peran komite sekolah dan paguyuban, dimana sekolah melibatkan Komite Sekolah dan paguyuban dalam proses pengawasan pelaksanaan serta meminta bantuan dalam bentuk materi, jasa dan pemikiran dalam pelaksanaan kegiatan pembiasaan; (4) Kepedulian wali murid menjadi salah satu pendukung yang sangat kuat dalam keberhasilan penguatan pendidikan karakter. Karena orang tua akan membantu anak menumbuhkan kesadaran agar mau mengikuti kegiatan pembiasaan dengan baik. Selain itu orang tua juga membantu sekolah dalam hal pendanaan atau dalam bentuk lainnya. Seperti pendanaan untuk kegiatan madin, sumbangan makanan untuk kegiatan bakti sosial dan lain sebagainya. Terkadang orang tua juga melaporkan tindakan peserta didik yang kurang baik pada paguyuban atau komite sekolah sehingga dapat ditindaklanjuti oleh sekolah; (5) Kesadaran peserta didik dalam melaksanakan juga menjadi salah satu kunci sukses pelaksanaan dari kegiatan pembiasaan. Karena ia adalah subjek dari kegiatan tersebut, maka biasanya juga akan mengimbas pada peserta didik yang tidak mau mengikuti dengan baik sehingga mau mengikuti dengan baik juga; (6) Sarana prasarana sekolah yang memadai salah satu faktor pendukung dalam pelaksanaan PPK melalui kegiatan pembiasaan di SMPN 1 Wlingi. Karena dalam pelaksanaannya memanfaatkan sarana dan prasarana yang ada di sekolah seperti ruang kelas, mushola, seperangkat audio sistem, dan ruang-ruang lainnya.

\section{Faktor penghambat pada program Penguatan Pendidikan Karakter melalui kegiatan pembiasaan dalam peningkatan mutu sekolah}

Sedangkan untuk faktor penghambatnya adalah (1) longgarnya komitmen guru dalam menjalankan perannya juga dapat melonggarkan keseriusan peserta didik dalam melaksanakan kegiatan pembiasaan, (2) kurangnya kesadaran peserta didik terhadap pelaksanaan, karena memang tak semua peserta didik bisa tertib saat tidak ada pengawasan, (3) kurangnya kepedulian wali murid juga membuat peserta didik tidak memiliki motivasi dalam melaksanakan kegiatan pembiasaan di sekolah, (4) keterbatasan sarana dan prasarana yang ada juga menjadi hambatan. Karena memang kegiatan pembiasaan memanfaatkan sarana dan prasarana yang ada. Seperti dalam pelaksanaan sholat berjamaah, mushola yang dimiliki sekolah tidak dapat menampung seluruh peserta didik, dan (5) sekolah memiliki 2 lokasi ini adalah kondisi yang jarang ditemui oleh sekolah lain sehingga ada beberapa kegiatan pembiasaan seperti upacara yang harus menyita banyak waktu karena mengumpulkan peserta didik dari 2 lokasi sekolah dalam 1 lokasi.

\section{Solusi dari faktor penghambat pada program Penguatan Pendidikan Karakter melalui kegiatan pembiasaan dalam peningkatan mutu sekolah}

Solusi dari faktor peghambat yang dialami adalah (1) longgarnya komitmen guru dalam menjalankan perannya juga dapat melonggarkan keseriusan peserta didik dalam melaksanakan kegiatan pembiasaan. Sehingga kepala sekolah melakukan pemantauan, pengawasan, pengarahan dan pembinaan yang biasanya dilakukan langsung di kelas maupun pada saat rapat dinas. Hal ini juga berlaku pada staf dan karyawan sekolah, (2) kurangnya kesadaran peserta didik terhadap pelaksanaan, karena memang tak semua peserta didik bisa tertib saat tidak ada pengawasan. Sehingga untuk mengatasi hal tersebut dibuatkan jadwal piket yang mana guru dan staf yang mendapat jadwal harus berkeliling mengawasi kegiatan pembiasaan. Petugas piket ini juga dibantu oleh guru agama, guru BK dan juga 
Waka Kesiswaan. (3) Kurangnya kepedulian wali murid juga membuat peserta didik tidak memiliki motivasi dalam melaksanakan kegiatan pembiasaan di sekolah. Maka dari itu, sekolah memberitahukan kepada orang tua terkait perilaku anak yang kurang baik melalui BK jika perilaku peserta didik yang dimaksud sudah berlebihan. (4) Keterbatasan sarana dan prasarana yang ada juga menjadi hambatan. Karena memang kegiatan pembiasaan memanfaatkan sarana dan prasarana yang ada. Seperti dalam pelaksanaan sholat berjamaah, mushola yang dimiliki sekolah tidak dapat menampung seluruh peserta didik sehingga pelaksanaan sholat berjamaah dini dilakuka secara bergilir dalam satu hari dan dibuat jadwal kelas yang melakukan sholat berjamaah pada hari itu. Namun, bagi peserta didik yang rumahnya jauh, Guru Agama menghimbau agar juga turus serta sholat berjamaah di sekolah. (5) Sekolah memiliki 2 lokasi ini adalah kondisi yang jarang ditemui oleh sekolah lain. Yang mana sekolah utara berisi ruang kelas 7 dan kelas 8, mushola, beberapa laboratorium, perpustakaan, ruang guru, posko PIK-R dan ASBN, kantin dan lapangan basket. Sedangkan sekolah selatan berisi ruang kelas 9, beberapa laboratorium, aula, ruang kepala sekolah, ruang guru, dan ruang TU. Sehingga terkadang dalam pelaksanaan kegiatan pembiasaan, peserta didik harus bolak balik ke sekolah utara dan ke sekolah selatan. Dan untuk solusinya dilakukan pengawasan agar tetap berjalan optimal dengan memberdayakan 2 satpam dan juga 2 guru yang bertanggung jawab dalam hal ketertiban untuk di masing-masing lokasi.

\section{PEMBAHASAN}

Program pembiasaan yang telah dilakukan oleh SMPN 1 Wlingi ini sudah diterapkan sebelum adanya PPK. Penggunaan kegiatan pembiasaan ini tentu memiliki alsan yang kuat. Karena memang penanaman karakter yang paling kuat adalah memalui kegiatan pembiasaan. Hal ini juga diungkapkan oleh Licktona (2008:87) bahwa pendidikan moral untuk anak memerlukan kegiatan secara berulangulang untuk melatih menjadi orang yang baik dimana anak harus diberikan kesempatan secara terus menerus berbuat jujur, bersikap santun dan adil sehingga menjadi sebuah kebiasaan yang selalu dilakukan dalam keadaan yang sulit sekalipun. Sehingga memang kegiatan pembiasaan ini adalah membentuk mindset serta karakter anak secara tidak langsung dengan menempatkan mereka pada posisi yang sama setiap hari atau berkali-kali. Hal inilah yang membuat pemerintah terus mengupayakan kegiatan yang berhubungan denagn pendidikan karakter dan menyampaikan himbauan pada seluruh sekolah. Memang sudah kewajiban sekolah bertanggung jawab atas penyusunan program sekolah sebagai wujud pendidikan yang sesuai dengan arah pendidikan yang ditentukan oleh pemerintah Prihatin (2011: 45). Maka dari proses perencanaan dari sekolah adalah (1) himbauan dari Pemerintah terutama Dinas Pendidikan Daerah; (2) Penyusunan SKL sekaligus kegiatan pembiasaan yang digunakan untuk mencapai SKL; (3) Pertemuan dengan Dewan Pendidikan (guru, Komite Sekolah, dan Perwakilan Paguyuban); (4) Penyusunan Buku 1 Kurikulum; (5) Pengintegrasian ke dalam RPP dan pembuatan jadwal pelajaran; (6) Penyusunan SOP untuk kegiatan pembiasaan; (7) Sosialisasi ke wali murid. Yang mana hal ini sesuai dengan pendapat Amri, dkk (2011: 31) bahwa pendidikan karakter juga bisa dikaitkan dengan sistem manajemen yang ada di sekolah mulai dari perencanaan sampai monitoring meliputi hal-hal seperti: nilai-nilai yang ditanamkan; muatan kurikulum; pembelajaran, penilaian, guru, staf dan karyawan, serta komponen lain yang terlibat.

Pelaksanaan PPK di SMPN 1 Wlingi diterapkan pada 3 basis dengan jenis kegiatan yang berbedabeda. Hal ini selaras dengan bentuk Implementasi yang dicanangkan oleh Tim PPK (2017:27), implementasi PPK dapat dilakukan dengan 3 pendekatan utama yaitu berbasis kelas, berbasis budaya sekolah, dan berbasis masyarakat. Dimana memang ketiga hal ini memiliki poin-poin yang semestinya dilaksanakan oleh sekolah sebagai salah satu bentuk program pendidikan karakter. Dimana memang SMPN 1 Wlingi menerapkan kegiatan pembiasaan dalam rangka untuk penerapan PPK yang sesuai dengan Perpres No. 87 mengenai Penguatan Pendidikan Karakter pasal 6 ayat 1 bahwa inti dari ayat terebut adalah menyebutkan penguatan pendidikan karakter diintegrasiikan ke dalam 3 aspek yakni intrakurikuler, kokurikuler dan ekstrakurikuler. Dimana memang dalam ketiga hal tersebut juga didukung dengan kegiatan rutin yang dilakukan di lingkungan sekolah maupun di kelas. 
Kegiatan pembiasaan yang dilakukan di SMPN 1 Wlingi untuk yang berbasis kelas adalah: Membaca kitab suci; kegiatan Pra KBM yang diantaranya adalah membaca Pancasila, menyanyi Lagu Indonesia Raya dan berdoa; kemudian kegiatan Literasi, berdoa setelah pembelajaran selesai; Melaksanakan piket kebersihan kelas sebelum dan sesudah pembelajaran; dan mengucapkan salam kepada guru sebelum dan sesudah pembelajaran. Dimana kegiatan pembiasaan ini diangkat dari Karakter Religius dan Akhlak Mulia serta Karakter Peduli Lingkungan. Dimana hal ini sejalan dengan Fathurrohman (2013:115) bahwa pendidikan karakter adalah salah satu usaha untuk menanamkan nilai-nilai baik pada peserta didik yang berkaitan dengan Tuhan YME, diri sendiri, sesama manusia, dan lingkungan serta kebangsaan berdasarkan norma-norma agama, hukum, tata krama, serta adat istiadat.

Berdasarkan temuan yang ada di SMPN 1 Wlingi, ada beberapa kegiatan yang terbiasa dilakukan di lingkungan sekolah, yang diantaranya adalah Bersalaman ketika bertemu guru; adanya etika dan aturan keluar masuk kelas dan sekolah dengan IKK dan IKS; Turun dari sepeda ketika memasukki gerbang sekolah; Budaya 5S (Salam, Senyum, Sapa, Sopan, dan Santun); Pelaksanaan upacara; Program adiwiyata: Kegiatan Keagamaan: sholat berjamaah dan kegiatan Madin dengan materi yang disampaikan adalah Fikih, Aqidah dan Akhlak, serta Usmani; dan Program ASBN dan PIK-R adalah program yang dibina oleh pihak luar sekolah guna menangani penyimpangan yang mungkin saja terjadi pada peserta didik. Kegiatan dari anggota kedua program ini lebih diarahkan untuk membantu kegiatan Adiwiyata. Dimana memang keseluruhan dari kegiatan tersebutlah yang membentuk karakter. Yang juga merupakan cara penerapan pendidikan karakter yang baik pada tingkat satuan pendidikan dalam rangka pembentukan budaya sekolah yang baik, atau jika dikaitkan dengan PPK adalah termasuk sebagai PPK berbasis budaya sekolah. Dimana memang pendidikan karakter bisa membentuk budaya sekolah sesuai dengan pendapat Amri, dkk (2011:31) bahwa "pendidikan karakter pada tingkatan instusi mengarah pada pembentukan budaya sekolah, yaitu nilai-nilai yang melandasi perilaku, tradisi, kebiasaan keseharian, dan simbol-simbol yang dipraktikan oleh semua warga sekolah dan masyarakat sekitar sekolah".

Dimana semua orang harus terlibat dalam implementasi PPK melalui kegiatan pembiasaan di SMPN 1 Wlingi sehingga untuk semua warga sekolah harus tetap saling mengingatkan dan memberi teladan terhadap warga sekolah yang lain secara konsisten karena telah menjadi kebiasaan. Seperti yang diungkapkan oleh Wibowo (2013:153) bahwa memang dalam pendidikan karakter diutamakan keteladanan dari semua warga atau komponen sekolah baik kepala sekolah, guru dan staf, harus selalu konsisten dalam kata, sikap dan perbuatan. Berdasarkan temuan dan teori yang ada, bahwa faktor pendukung dan penghambat dalam implementasi PPK melalui kegiatan pembiasaan adalah meliputi dari beberapa aspek seperti peserta didik, guru, sarana dan prasarana, serta orang tua peserta didik. Hal yang menjadi pendukung dalam pelaksanaan program PPK dalam kegiatan pembiasaan juga menjadi penghambat. Contoh yang menjadi pendukung dan hambatan dalam pelaksanaan pendidikan karakter yang ditemukan dalam penelitian dari Fortunata (2017:72) adalah meliputi beberapa aspek yang diantaranya peserta didik, waktu, guru, dan fasilitas sekolah. Tanpa adanya dukungan dari ke empat aspek tersebut, PPK yang berjalan di SMPN 1 Wlingi melalui kegiatan pembiasaan tidak dapat berjalan dengan baik. Sehingga memang ke empat hal tersebut harus bersinergi dalam mensukseskan pendidikan karakter yang ada di sekolah dengan dukungan dari sistem yang ada di sekolah yang sudah tersusun mulai dari kurikulum sekolah, tata tertib sampai cara sekolah yang digunakan untuk mengatasi permasalahan yang terjadi.

\section{KESIMPULAN DAN SARAN}

\section{Kesimpulan}

Implementasi program PPK melalui kegiatan pembiasaan dalam meningkatkan mutu sekolah dimulai dengan melakukan perencanaan kegiatan melalui SPMI dan penyusunan SKL yang akan berdampak pada perubahan kurikulum, RPP, jadwal pelajaran, dan tersusunnya SOP pelaksanan. Dimana kegiatan perencanaan ini menghasilkan kegiatan pembiasaan di 2 basis yakni basis kelas dengan kegiatan yang dilakukan adalah Membaca kitab suci; kegiatan Pra KBM yang diantaranya adalah membaca Pancasila, menyanyi Lagu Indonesia Raya dan berdoa; kemudian kegiatan Literasi, berdoa setelah pembelajaran 
selesai; Melaksanakan piket kebersihan kelas sebelum dan sesudah pembelajaran; dan mengucapkan salam kepada guru sebelum dan sesudah pembelajaran Membaca kitab suci; kegiatan Pra KBM yang diantaranya adalah membaca Pancasila, menyanyi Lagu Indonesia Raya dan berdoa; kemudian kegiatan Literasi, berdoa setelah pembelajaran selesai; Melaksanakan piket kebersihan kelas sebelum dan sesudah pembelajaran; dan mengucapkan salam kepada guru sebelum dan sesudah pembelajaran. Sedangkan untuk yang berbasis budaya sekolah adalah Bersalaman ketika bertemu guru; adanya etika dan aturan keluar masuk kelas dan sekolah dengan IKK dan IKS; Turun dari sepeda ketika memasukki gerbang sekolah; Budaya 5S (Salam, Senyum, Sapa, Sopan, dan Santun); Pelaksanaan upacara; Program adiwiyata: Kegiatan Keagamaan: sholat berjamaah dan kegiatan Madin; dan Program ASBN dan PIK-R. Dan untuk mensukseskan kegiatan pembiasaan tersebut dilibatkan seluruh komponen yang terkait dengan sekolah untuk tetap mendukung. Namun, segala hal yang mendukung juga bisa menjadi hambatan jika tidak dimaksimalkan seperti dari aspek: warga sekolah (guru, staf dan karyawan), peserta didik, sarana dan prasarana serta orang tua.

\section{Saran}

Berdasarkan kesimpulan di atas terdapat beberapan saran untuk beberapa pihak yang terkait dengan subjek penelitina ini, yang diantaranya: (1) Bagi Kepala Dinas Pendidikan Kabupaten Blitar, disarankan untuk membuat kebijakan yang lebih berorientasi pada kebutuhan dan keadaan sekolah dan lingkungannya; (2) Bagi Kepala SMPN 1 Wlingi, disarankan lebih meningkatkan kekompakan dan kerja sama dari seluruh warga sekolah; (3) Bagi Guru SMPN 1 Wlingi, disarankan untuk meningkatkan kesadarannya dan kepeduliannya kepada peserta didik sehingga bisa berkomitmen untuk datang lebih pagi agar bisa melaksanakan kegiatan pembiasaan di pagi hari: (4) Bagi Tenaga Administrasi SMPN 1 Wlingi, disarankan untuk tidak hanya menjalankan tugas yang diperintahkan, namun juga peduli terhadap pembentukan budaya yang baik untuk memberikan penguatan karakter pada peserta didik melalui kegiatan pembiasaan setiap harinya; (5) Bagi Dosen Jurusan Administrasi Pendidikan Fakultas Ilmu Pendidikan di Universitas Negeri Malang, disarankan agar digunakan sebagai bahan referensi dalam pengembangan ilmu pengetahuan; dan (6) Bagi peneliti lain, disarankan agar hasil penelitian ini dijadikan sebagai bahan pertimbangan dan referensi untuk penelitian selanjutnya dan lebih bisa dikembangkan dengan topik-topik yang lebih mendalam.

\section{DAFTAR RUJUKAN}

Azwar, K. 2017. Program FDS Dorong Pendidikan Karakter, (Online), (www.republika.co.id), diakses 10 April 2017.

Fathurrohman, P., Suryana AA., \& Fatriany, F. 2013. Pengembangan Pendidikan Karakter. Bandung: PT Refika Aditama.

Fortunata, S. F. 2017. Manajemen Pendidikan Berbasis Budaya Religi (Studi Multi Situs di SDN Rampal Celaket 2 Malang dan SDN Purwodadi 1 Malang). Skripsi tidak diterbitkan. Malang: FIP UM.

Hamid, A. 2017. Pendidikan Karakter Berbasis Pesantren: Pelajar dan Santri dalam Era IT \& Cyber Culture. Surabaya: IMTIYAZ.

Kemendikbud. 2017. Pengertian, Konsep Dasar, dan Manfaat Penguatan Pendidikan Karakter serta Hal Penting Terkait PPK yang Wajib Guru Pahami, (Online), (www.infokemendikbud.com), diakses 10 April 2017.

Lickona, T. 2013. Pendidikan Karakter: Panduan Lengkap Mendidik Siswa Menjadi Pintar dan Baik. Bandung: Penerbit Nusa Media. 2008.

Prihatin, E. 2011. Manajemen Peserta Didik. Bandung: Alfabeta.

Tim PPK. 2017. Konsep dan Pedoman Penguatan Pendidikan Karakter: Tingkat Sekolah Dasar dan Sekolah Menengah Pertama. Jakarta: Tim PPK Kemendikbud.

Wibowo, A. 2013. Manajemen Pendidikan Karakter di Sekolah. Yogyakarta: Pustaka Belajar. 